\title{
A branch of the financial risk analysis and countermeasures
}

\author{
Liang Yunji, Bu Lijun \\ The Accounting College of Harbin University of Commerce, China
}

Keywords: industrial and commercial bank; Financial risk; Risk assessment; Risk response

\begin{abstract}
A branch, according to the actual situation of A branch, financial risk analysis, and then pointing to A branch of the financial risk, put forward the corresponding countermeasures.
\end{abstract}

\section{A branch of the general situation of}

\subsection{Introduction to A branch}

A branch belongs to the industrial and commercial bank, the branch was established in 1991, the numerous customers, especially the mobile client is more, comprises six branch of industrial and commercial bank of A branch, A total of 383 employees. The bank's business mainly include deposits, short-term mortgage, transfer, exchange, discount, cashier, etc., in addition to conduct business in financial business have cash management, collecting payments, trust, lease and etc, one of the main profitable business for the deposit and loan business.

A branch of industrial and commercial bank of the end of 2014, the total assets in the table is 269 . 7.6 billion yuan. Among them, the RMB: 17.013 billion yuan, each foreign currency: $\$ 1.614$ billion. Liabilities, the total debt in the table into RMB 26.706 billion yuan. Among them, the RMB: 17.02 billion yuan, each foreign currency: \$1.553 billion.

\subsection{A branch operation status}

The table 1 shows that A branch in 2014, operating income and net profit more than 10.4 billion yuan and 4.5 billion yuan respectively. Among them, the main source of revenue is the bank loan interest, this part of the income of up to 9 billion yuan, $86 \%$ in revenue, income structure is more traditional, thus A branch is still in the credit as the main business. Although credit income is higher, but also brought the corresponding financial risk. Data in the table also shows that the branch source of revenue and $11 \%$ is the handling charge commissions, the other is about $4 \%$ of investment gains. Formal in recent years, frequent outbreak of financial crisis, the financial industry ushered in the era after the financial crisis, the upheavals in the face of such situation, many Banks began to realize that simply relying on the difference of the savings and loan for earnings of the traditional mode of operation has won't work, so all onto the road of business transformation, actively explore the transformation path. In addition, the exchange of A branch of the present A negative net income, the main cause of this phenomenon lies in the adjustment of bank interest rates, exchange rates is not stable, the benefits of external assets so severely affected. From the point of data statistics, since 2013, A branch for two consecutive years of net profit have larger growth, especially in 2014, compared to last year's net profit increased nearly 490 million yuan, is basically the same percentage of the sales, but two years in business spending A show that only $1 \%$ of the tiny differences.

\section{A branch of the financial risk analysis}

\subsection{The risk of asset quality}

Bank assets as a result of all kinds of risks are referred to as asset quality risk. Through active development of A branch, bank of broader scope of business; In terms of asset quality risk also made a lot of effort, to carry out the assets business prudence, for all kinds of vigilance is likely to 
lead to the risk factors, bank risk to get a degree of control. But for now, the branch's core business is still the traditional credit.

Table 1 A branch 2013-2014, profit and loss structure analysis

\begin{tabular}{|c|c|c|c|c|}
\hline & \multicolumn{2}{|c|}{2014} & \multicolumn{2}{|c|}{2013} \\
\hline & $\begin{array}{l}\text { Figure(Ten } \\
\text { thousand) }\end{array}$ & Sales percentage & $\begin{array}{l}\text { Figure(Ten } \\
\text { thousand) }\end{array}$ & $\begin{array}{c}\text { Sales } \\
\text { percentage }\end{array}$ \\
\hline Revenue & 1047829.40 & $100.00 \%$ & 911555.30 & $100.00 \%$ \\
\hline Net interest income & 909627.10 & $86.81 \%$ & 769551.50 & $84.43 \%$ \\
\hline Interest income & 2076825.50 & 198. $20 \%$ & 1674117.10 & $183.68 \%$ \\
\hline Minus: Interest expense & 1167198.40 & $111.39 \%$ & 904565.60 & $99.25 \%$ \\
\hline $\begin{array}{l}\text { Auxiliary expenses and Net } \\
\text { commission income }\end{array}$ & 118027.00 & 11. $26 \%$ & 92537.50 & $10.15 \%$ \\
\hline Net investment income & 37247.70 & $3.55 \%$ & 48102.10 & $5.28 \%$ \\
\hline $\begin{array}{l}\text { Net income from changes in fair } \\
\text { value }\end{array}$ & -6512.70 & $-0.62 \%$ & 1803.00 & $0.20 \%$ \\
\hline Other operating net income & 19814. 40 & $1.89 \%$ & 49204.30 & $5.40 \%$ \\
\hline Exchange net income & -13278.00 & $-1.27 \%$ & -1731.50 & $-0.19 \%$ \\
\hline $\begin{array}{l}\text { Net income from other } \\
\text { operations }\end{array}$ & 2357.40 & $0.22 \%$ & 1030.70 & $0.11 \%$ \\
\hline operating expenditure & 491660.50 & $46.92 \%$ & 415661. 20 & $45.60 \%$ \\
\hline Business taxes and surcharges & 84037.10 & $8.02 \%$ & 64477.80 & $7.07 \%$ \\
\hline Management expense & 325166.20 & $31.03 \%$ & 272121.10 & $29.86 \%$ \\
\hline Assets impairment loss & 82096. 30 & $7.83 \%$ & 78910.30 & $8.66 \%$ \\
\hline Operating profit & 556168.90 & $53.08 \%$ & 495784.10 & $54.40 \%$ \\
\hline Add: Non operating income & 6434.00 & $0.61 \%$ & 3941.50 & $0.43 \%$ \\
\hline $\begin{array}{l}\text { Subtract: Non operating } \\
\text { expenditure }\end{array}$ & 1750.80 & $0.17 \%$ & 1685.20 & $0.18 \%$ \\
\hline Total profit & 560852.10 & $53.53 \%$ & 498040.40 & $54.64 \%$ \\
\hline Subtract: Income tax & 10795. 10 & $10.29 \%$ & 93587.80 & $10.27 \%$ \\
\hline Net profit & 453057.00 & $43.24 \%$ & 404452.60 & $44.37 \%$ \\
\hline Subtract: minority interests & 3371.30 & $0.32 \%$ & 3192.30 & $0.35 \%$ \\
\hline $\begin{array}{l}\text { Net profit attributable to owners } \\
\text { of the parent company }\end{array}$ & 449685.70 & $42.92 \%$ & 401260.30 & $44.02 \%$ \\
\hline $\begin{array}{l}\text { Add: other comprehensive } \\
\text { income }\end{array}$ & -131980.30 & $-12.60 \%$ & -14736.10 & $-1.62 \%$ \\
\hline Total comprehensive income & 321076.70 & $30.64 \%$ & 389716.50 & $42.76 \%$ \\
\hline $\begin{array}{l}\text { Subtract: attributable to } \\
\text { minority shareholders of total } \\
\text { consolidated income }\end{array}$ & 3371.60 & $0.32 \%$ & 3192.30 & $0.35 \%$ \\
\hline $\begin{array}{l}\text { The total amount of } \\
\text { comprehensive income } \\
\text { attributable to the parent } \\
\text { company of ordinary } \\
\text { shareholders }\end{array}$ & 317705.10 & $30.32 \%$ & 386524.20 & $42.41 \%$ \\
\hline Primary earnings per share & 1.51 & - & 1.35 & - \\
\hline Earnings per share & 1.51 & - & 1.35 & - \\
\hline
\end{tabular}

The branch are still focusing on traditional credit business, so their sources of income also is given priority to with loan income, bank assets structure in loan account for high proportion. The traditional business because is affected by many uncertain factors, there is not controllable, because a lot of interest on the loan borrowers' credit risk and will not be repaid, perhaps even a principal to fail due to the bad loans and other major risk. In fact, no matter which bank is unable to fully control the credit risk, it is undeniable the main risk, because the credit risk and to the collapse of the bank, the credit risk is usually not directly, but through the impact on the bank's liquidity. 


\subsection{The liquidity risk}

Liquidity risk refers to the bank capital is not enough to cope with the maturity of the debt or asset growth and cause of risk. About the detection of liquidity, the China banking regulatory commission made the related measures, including asset-liability ratio and cash flow ratio is two important reference index.

A branch of the assets of 25.835 billion yuan in 2013, debt is 25.574 billion yuan, asset-liability ratio is as high as $98.99 \%$, industrial and commercial bank of 2014. J branch 269 of assets 7.6 billion yuan, the debt is 26.706 billion yuan, asset-liability ratio is $99.3 \%$, the ratio of these two years, the branch has A rising trend, and reasonable (for example, the agricultural bank, bank of communications, etc.) of the asset-liability ratio is between $90 \%$ and $92 \%$, and has been relatively stable, indicating that A branch of the asset-liability ratio is too high, there is A big risk of credit business, is likely to be followed by A larger credit crisis.

\subsection{Capital risk}

Capital risk refers to the reserves to the bank capital is not enough to pay due debts, its solvency and risk bearing capacity is affected, which leads to safety concerns. Modern bank capital requirements, risk management bank in order to meet the requirements of its development in later stage, should reserve enough capital, this is a bank to deal with debts, to maintain its survival and development of the most basic premise. For now, the branch of capital mainly comes from two aspects.

\section{A branch of the financial risk coping strategies}

\subsection{Set up financial risk control strategy}

Based on A branch operation situation and situation of financial risk, it can be seen that there is A branch of non-performing loans ratio is higher, low capital adequacy ratio and loan business is concentrated risk, profit level generally, accounting internal control system is lax executive force is not strong, partial high, the financial risk of these problems, investigate its root cause is not A branch from the height of the strategic management of financial risk control. Therefore, it is imperative that A branch set up feasible financial risk control strategy, efforts to achieve the comprehensive risk management, risk control and A full and full risk quantitative risk culture construction, should not only consider the long-term development targets, and based on the current situation of risk management.

\subsection{The financial risk of the implementation of centralized and unified management organizational structure}

Centralized financial management organization structure is the only way to implement strategy of financial risk management, A branch to be in accordance with the requirements of the international advanced bank risk management system construction, practical and fundamental reform from the whole bank governance structure, to the bank to achieve the goal of strategic management, financial risk to provide feasible organization guarantee.

\section{References}

[1] Fu yao.Bank financial management system of research [J]. J., 2014 (05)

[2] Li he. Domestic commercial bank financial risk management research [J]. 2015 (08) wuhan financial.

[3] Yang yunyun.Policy Banks risk management research review [J]. Journal of finance development research. 2015 (12)

[4] Zhang Wei, Qiu Yong. Portfolio default risks of multi-bank loan pools [J]. Journal of management science in China, 2008,11(4) 
[5] Zong xiaopeng, Huang Feng, YangChaojun.liquidity demand of investors and assets pricing[J]. Journal of management science in China, 2009,12(6) 